Micropropagation of axillary shoots of hybrid chestnut (Castanea sativa $\times$ C. crenata) in liquid medium in a continuous immersion system

B Cuenca ${ }^{1}$, C Sánchez ${ }^{2}$, A Aldrey², B Bogo² + , B Blanco² ${ }^{2}$ B Correa², N Vidal ${ }^{2}$

TRAGSA. Vivero de Maceda. Ctra. Maceda-Valdrey km 2. 32700 Maceda, Ourense (Spain).

Instituto de Investigaciones Agrobiológicas de Galicia, CSIC, Apdo 122. 15780 Santiago de Compostela (Spain).

$\dagger$ deceased

This research was published in Plant Cell Tiss. Organ Cult. 2017, 131, 307-320.

DOI 10.1007/s11240-017-1285-5 


\section{Micropropagation of axillary shoots of hybrid chestnut (Castanea sativa $\times$ C. crenata) in liquid medium in a continuous immersion system}

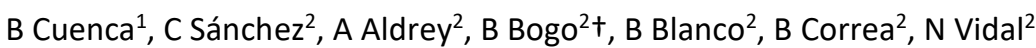

TRAGSA. Vivero de Maceda. Ctra. Maceda-Valdrey km 2. 32700 Maceda, Ourense (Spain).

Instituto de Investigaciones Agrobiológicas de Galicia, CSIC, Apdo 122. 15780 Santiago de Compostela (Spain).

$\dagger$ deceased

Keywords: bioreactors, Castanea, forced ventilation, large-scale propagation

\section{Abstract}

A protocol for culturing chestnut axillary shoots with the basal sections continuously immersed in liquid medium was developed and the influence of various parameters was assessed: explant type and size, support material, bioreactor size and aeration regime. Shoots excised from eight selected chestnut genotypes were successfully cultured in $10 \mathrm{~L}$ bioreactors in liquid Murashige and Skoog medium with half strength nitrates and supplemented with $0.05 \mathrm{mg} / \mathrm{L} \mathrm{N}^{6}$-benzyladenine and $30 \mathrm{~g} / \mathrm{L}$ sucrose. Forced ventilation and the use of a support material were essential for producing healthy, non-hyperhydric shoots. High proliferation rates were achieved and good quality shoots ready for multiplication, rooting and acclimatization were obtained. Larger leaves showing higher levels of photosynthetic pigments were observed in shoots cultured in bioreactors, suggesting a certain degree of photoautotrophy in shoots cultured under forced ventilation. This is the first demonstration of the production of chestnut shoots in stationary liquid medium, indicating the feasibility of the method for large-scale propagation of the species.

Key message:

Chestnut shoots were micropropagated for the first time by continuous immersion in liquid medium. The use of support material and forced aeration were essential for successful growth.

\section{Author Contribution Statement:}

$B C, C S$ and NV conceived and designed the experiment. NV, $A A, B B, B B$ and $B C$ performed the experiments and analysed and interpreted the data. NV and CS wrote the manuscript. All authors read and approved the final manuscript.

\section{Conflict of Interest:}

The authors declare that they have no conflict of interest.

\section{ACKNOWLEDGEMENTS}

We acknowledge the contribution of our dear colleague and friend, Brais Bogo Graña, who died before completion of the manuscript. We thank Alejandro Díaz, Rafael Sánchez and Patricia Val for technical 
assistance. This research was partly funded through the FEDER INNTERCONECTA 2013/2014 programme (project INTEGRACASTANEA EXP00064828/ITC-20133040).

\section{INTRODUCTION}

The use of liquid medium is ideal for large-scale micropropagation (Etienne and Berthouly 2002). We recently evaluated the use of a temporary immersion system (TIS) for chestnut micropropagation and reported successful proliferation, rooting and acclimatization of shoots of eight genotypes selected for their resistance to ink disease, indicating the feasibility of culturing chestnut tissues without the use of gelling agents (Vidal et al. 2015a). In the previous study, we compared several bioreactors, of which plantform ${ }^{\mathrm{TM}}$ was the most productive and the easiest to manage.

However, in the experiments carried out with the TIS, we observed that the shoots of some genotypes reached the top of the commercial containers before the stems were sufficiently thick or vigorous enough to undergo the rooting and acclimatization processes. Within the different approaches used to overcome this limitation, we explored the proliferation of chestnut shoots in a continuous immersion system (CIS), using different bioreactors that would provide more space for the explants to grow and develop larger leaves and would possibly induce photoautotrophy.

Woody plants such as Eucalyptus (Nagae et al. 1996, Tanaka et al. 2005), Actinidia deliciosa (Feito et al. 2001), Acacia nilotida (Rathore et al. 2014) and Dalbergia sissoo (Vibha et al. 2014) have been cultured in CISs. However, to the best of our knowledge, these systems have not yet been applied to chestnut, except in a preliminary study by our research group (Vidal et al. 2015b).

One of the drawbacks of liquid culture involving continuous immersion of explants is that the concentration of oxygen in liquid media is often insufficient to meet the respiratory requirements of the submerged tissues. However, the oxygen concentration of the medium can be increased either by agitation, bubbling or, in stationary systems, by placing the tissues in direct contact with air (Thorpe et al. 2008). This can be easily done when the shoot masses transferred to stationary liquid medium are large enough to remain above the liquid phase (Preece, 2010), or by using a porous support material, such as paper, foam, rockwool or vermiculite (Thorpe et al. 2008). The gaseous environment of the explants can be further improved by increasing natural ventilation by the use of gas-permeable films or by forced ventilation, i.e. mechanically moving filtered air from the outside to the inside of a culture vessel and vice versa with the aid of an air pump (Zobayed, 2005).

The aim of the present study was to evaluate the feasibility of propagating chestnut shoots in a CIS by applying a stationary approach with forced ventilation. Explants of eight genotypes were tested and the effects of parameters such as explant type, size and source, support material, bioreactor type and frequency of aeration were evaluated.

\section{MATERIALS AND METHODS}


The eight chestnut genotypes used in this study were selected for their resistance to ink disease. One of the genotypes is an artificial hybrid of Castanea sativa $\times$ C. crenata (clone 90025), whereas genotypes C003, C042, C053, C063, P028, P042 and P043 were recently characterized as natural hybrids of $C$. sativa and C. crenata (González et al. 2011). All genotypes were previously established in vitro from young ramets (artificial hybrid) and basal sprouts (natural hybrids) (Vidal et al. 2010). Stock cultures were maintained either in semi-solid (SS) medium in $500 \mathrm{ml}$ glass jars or in a temporary immersion system consisting of plantform ${ }^{\mathrm{TM}}$ vessels (Vidal et al. 2015a) containing MS (Murashige and Skoog, 1962) medium with half strength nitrates and supplemented with $0.05 \mathrm{mg} / \mathrm{L} \mathrm{BA}$ and $3 \%$ sucrose (Multiplication Medium; MM). All media were autoclaved at $121^{\circ} \mathrm{C}$ for $20 \mathrm{~min}$ after adjustment of the $\mathrm{pH}$ to 5.7. For gelling, $0.7 \%$ (w/v) Bacto agar was added to the SS medium prior to $\mathrm{pH}$ adjustment.

In preliminary experiments, basal sections of clone 90025, attached to the basal callus and bearing 2-3 nodes (Fig. 1a), were cultured in liquid medium in 1 L RITA ${ }^{\circledR}$ vessels (www.vitropic.fr) without the inner baskets and equipped with $0.2 \mu \mathrm{m}$ air filters (Fig. 1b). The RITA ${ }^{\circledR}$ vessels each contained $150 \mathrm{ml}$ of MM and 12 explants. The cultures were aerated, or not, for $2 \mathrm{~min}$ at a frequency of 16 times every 24 hours, and the use of support material was evaluated. Cultures were incubated under a 16-h photoperiod, provided by cool-white fluorescent lamps $\left(50-60 \mu \mathrm{mol} \mathrm{m} \mathrm{m}^{-2}\right)$, and a $25{ }^{\circ} \mathrm{C}$ light $/ 20{ }^{\circ} \mathrm{C}$ dark temperature regime and were subcultured every 5 weeks (standard conditions).

In subsequent experiments, we compared the use of $\mathrm{RITA}^{\circledR}$ vessels and $10 \mathrm{~L}$ rectangular polypropylene containers adapted in our laboratory from Lock\&Lock ${ }^{\circledR}$ food containers (Fig. 1c, d) and referred to here as C10 bioreactors. The C10 bioreactors were also equipped with $0.2 \mu \mathrm{m}$ air filters, but contained $1000 \mathrm{ml}$ of MM and 36 explants. The cultures were aerated for $2 \mathrm{~min}$ at a frequency of 16 times every 24 hours and were grown under standard conditions.

The following parameters were evaluated for application of CIS to chestnut cultures: 1) type of bioreactor; 2) support material (perlite, vermiculite, glass beads or rockwool cubes); 3) explant type (apical or basal segments attached to the basal callus; Fig. 1a); 4) explant size (1.5 or $3 \mathrm{~cm})$; 5) frequency of aeration; 6) rooting and acclimatization capacity of shoots; and 7) type of culture system (SS medium or CIS).

The following responses were recorded: a) the percentage of normal explants, i.e. healthy explants lacking any sign of hyperhydricity (\% NE); b) the number of normal shoots longer than $1.5 \mathrm{~cm}$ produced by each explant; c) the multiplication coefficient (MC), calculated as the number of new segments obtained from each initial explant; d) the length of the longest shoot per explant (SL); e) the number of rootable shoots (RS) per explant (i.e. vigorous shoots longer than 3-4 cm, non-hyperhydric and with an actively growing apex); f) the length (LL) and width (LW) of the largest leaf per explant, used to calculate the leaf area (LA) as $1 / 2 L^{*} L W ; g$ ) the percentage of rooted and acclimated shoots relative to all shoots subjected to the root induction process (\% RAS); and h) the level of photosynthetic pigments.

For quantitation of leaf parameters, explants were cultured in jars with SS medium and in C10 bioreactors with liquid medium. After 5 weeks, the uppermost two expanded leaves of 6 explants per vessel were 
measured and weighed and the explants were then submerged in dimethylformamide (Fig. 1e). The vessels were incubated for $8 \mathrm{~h}$ in darkness, and the chlorophyll a, b and total carotenoids were quantified spectrophotometrically following the method described by Wellburn (1994).

Adventitious rooting was induced ex vitro by dipping the bases of the shoots in $1 \mathrm{~g} / \mathrm{L}$ indole-3-butyric acid (IBA) for 1 min and then transferring the shoots to Root! $t^{\circledR}$ sponges (Hydrogarden), Jiffy ${ }^{\circledR}$ pots (Telegrow) or $37 \times 37(\mathrm{~mm})$ rockwool cubes (Grodan), all moistened with MS medium with $1 / 2$ strength macronutrients but without sugar or plant growth regulators. For root emergence, shoots were placed in a phytotron for 4 weeks (16 h photoperiod, $25{ }^{\circ} \mathrm{C}$ light/20 ${ }^{\circ} \mathrm{C}$ dark temperature regime, $90 \%$ moisture) before being transferred to pots containing peat:perlite (3:1), for acclimatization for a further 4 weeks in the greenhouse.

For statistical analysis, unless otherwise stated, 12 or 24 explants were used per treatment, and each experiment was repeated at least twice. Levene's test was used to verify homogeneity of variances and the Shapiro-Wilk test was used to check for error normality. The data were then subjected to analysis of variance followed by Tukey-b test for comparison of group means. The Welch ANOVA and Games-Howell post-hoc comparison were used when heteroscedasticity was detected, and the non-parametric KruskalWallis $\mathrm{H}$ test was used for non-normally distributed data. Percentage data were subjected to arcsine transformation prior to analysis.

\section{RESULTS AND DISCUSSION}

\section{Preliminary experiments}

The initial experiments were performed with basal explants of clone 90025 cultured in commercial RITA ${ }^{\circledR}$ containers without the inner baskets (Fig. 1b). The explants were placed between rockwool cubes or were directly submerged in the liquid medium, and forced aeration of 2 min of duration was applied 0 or 16 times every 24 hours. After 5 weeks, only the explants cultured with cubes and aeration developed vigorous shoots with expanded leaves and normal apexes (Fig. 1f), whereas the explants placed between rockwool cubes with no aeration produced short shoots with curly leaves (Fig. 1g) and could not be subcultured. When aeration but no support was provided, the explants were severely hyperhydric and visibly swollen (Fig. 1h) and also could not be used for multiplication. Hyperhydricity (formerly called vitrification) is a serious problem in chestnut culture, even when gelled medium is used (Vieitez et al. 1985), and has been considered the main obstacle to culturing European chestnut shoots in liquid medium (Troch et al. 2010). This disorder has been related, among other causes, to waterlogging (Rojas-Martínez et al. 2010). Hyperhydricity has also been linked to inadequate support or aeration. Thus, Moncaleán et al. (1999) reduced hyperhydricity in Actinidia deliciosa explants from 57 to $25 \%$ by using cellulose plugs instead of quartz sand as support material. Chakrabarty et al. $(2003,2007)$ were only able to propagate apple in a continuous immersion system by using a supporting net to prevent the explants being completely submerged. Savio et al. (2012) highlighted the need to maintain at least some sections of the shoots above the medium to prevent hyperhydricity in Hypericum perforatum. Kiferle et al. (2014) 
detected this disorder in sweet basil grown in CIS without support material, and Petrova et al. (2014) observed hyperhydricity and poor growth in Arnica montana explants cultured in stationary liquid medium without ventilation.

The preliminary results with chestnut explants cultured in CIS (Fig. 1f-h) showed that support material and forced aeration were necessary in order to produce shoots that could be multiplied, and these requirements were therefore met in the remaining experiments. Saéz et al. (2012) observed improved growth of chestnut shoots cultured in agar-based medium in Magenta ${ }^{\mathrm{TM}}$ vessels with natural ventilation; however, to the best of our knowledge, forced ventilation has not previously been applied in culturing this species. The use of forced ventilation has improved propagation of other plants (Kozai and Kubota 2005) and may be particularly advantageous when large containers are used (Zobayed 2005). It also enables manipulation of the aerial environment inside the bioreactors and can enhance the photoautotrophic behaviour of the shoots (Xiao et al. 2011).

\section{Type of bioreactor}

For purposes of comparison, clones C063 and P028 were cultured in RITA ${ }^{\circledR}$ containers (total volume $1 \mathrm{~L}$, $150 \mathrm{ml}$ of medium) and C10 bioreactors (adapted food containers, volume $10 \mathrm{~L}, 1000 \mathrm{ml}$ of medium). Basal explants of length $1.5 \mathrm{~cm}$ were used (12 explants per RITA ${ }^{\circledR}$ vessel and 36 explants per C10 vessel). After 5 weeks, the proportion of normal (non-hyperhydric) explants was similar in both containers for both clones (Table 1), although differences in the other variables were observed. In clone P028, RITA ${ }^{\circledR}$ and C10 vessels yielded similar results, whereas in clone C063, larger containers produced more and taller shoots, a higher multiplication coefficient, a greater number of rootable shoots and longer leaves (Table 1). The existence of genotypic differences related to the micropropagation of woody plants such as chestnut has been reported (Vieitez et al. 2007), indicating the need for more than one genotype to be tested when developing a new protocol. In this study, C10 containers yielded higher proliferation of clone C063, and no negative effect was detected with clone P028. Use of shelf space was also more efficient with the rectangular C10 bioreactors than with cylindrical RITA ${ }^{\circledR}$ flasks, and therefore the 10 litre containers were subsequently used for large-scale propagation. However, RITA ${ }^{\circledR}$ vessels were more efficient as regards the amount of medium required for each explant, and these vessels may represent a good choice when plant material is scarce. Large vessels may reduce labour costs (Xiao et al. 2000) and have been used for continuous immersion propagation of other woody plants such as Eucalyptus camaldulensis (Zobayed et al., 2000), Paulownia fortunei (Nguyen and Kozai, 2001), Coffea arabusta (Nguyen et al. 2001) and Vitis vinifera (Nguyen et al. 2016).

\section{Aeration regime}

Shoots of some genotypes grew slowly during the first weeks of culture in the $10 \mathrm{~L}$ bioreactors, thus hampering their subsequent development. Kozai (1991) reported that excessive ventilation may have an adverse effect on micropropagation. Two different aeration regimes were evaluated to determine any improvement in proliferation of chestnut cultured in the $\mathrm{C} 10$ containers. In the control treatment, 
aeration was provided for 2 minutes, 16 times day during the 5 weeks of the experiment, whereas in the other treatment, no aeration was provided during the first week of the experiment. For clones C063 and P028, the lack of aeration during the first week of culture led to significant improvements in the proliferation parameters (Fig. 2). Longer shoots, a higher multiplication coefficient and a greater number of rootable shoots were obtained, and this aeration regime was therefore applied in the remaining experiments. Similar results were obtained with Scrophularia yoshimurae, as more shoots were produced when aeration was provided only during the last 4 weeks of the 8-week culture period (Lai et al. 2005). The aforementioned authors measured the ethylene levels inside the vessels during propagation and postulated that relatively high levels of ethylene were necessary during the first weeks of culture for bud formation, whereas posterior removal of this gas prevented hyperhydricity. Nour and Thorpe (1994), Dimassi-Theriou and Economou (1995), and González et al. (1997) reported a positive correlation between ethylene concentration and the number of shoots produced by respectively peach, cedar and poplar explants. Mingozzi et al. (2009) indicated the need for a certain amount of ethylene for development of buds of Populus deltoides, but that this gas may escape if excessive aeration is applied. In our study with chestnut, it is possible that the aeration applied during the first week of culture caused an excessive decrease in the ethylene levels inside the vessels, hampering the formation and growth of new buds; however, we did not carry out the measurements necessary to clarify this aspect.

\section{Support material}

Perlite, vermiculite, glass beads and rockwool cubes were used to maintain the vertical position of chestnut shoots (Fig. 1i). The effect of these different types of support on the proliferation of basal explants of clone 90025 is shown in Fig. 3. Perlite has been used with Limonium latifolium and Solanum tuberosum (Xiao et al. 2000), whereas rockwool cubes have been used with Spathiphyllum (Tanaka et al. 1992), Eucalyptus citriodora (Nagae et al. 1996), Cymbidium (Norikane et al. 2010) and Oncidesa (Norikane et al. 2013). Vermiculite has been used as a substrate for Eucalyptus camaldulensis (Kirdmanee et al 1995), Garcinia mangostana (Ermayanti et al. 1999), Paulownia fortune (Nguyen and Kozai 2001) and Samanea saman explants (Mosaleeyanon et al. 2004), and glass beads have been used as a substrate for Rauwolfia serpentina (Goel et al. 2007) and Hypericum perforatum (Goel et al. 2009). In chestnut, all substrates yielded healthy shoots (with almost no hyperhydricity) with large leaves (averaging $45 \mathrm{~mm}$ length and 14 $\mathrm{mm}$ width, with no significant differences between substrates). However, the use of vermiculite had a negative influence on the number and length of the new shoots, causing a significant decrease in the multiplication coefficient and the number of rootable shoots. Rockwool cubes yielded the highest levels of proliferation and were used in subsequent experiments. This material also performed well in our previous study of chestnut cultured in a TIS (Vidal et al. 2015a).

\section{Explant type and size}

In a previous study, basal segments attached to the basal callus proved to be the best type of chestnut explant for culture in liquid medium in a TIS, in relation to proliferation rate, shoot quality and number of 
rootable shoots yielded (Vidal et al. 2015a). These basal sections were therefore used as explants in the initial experiments with CIS in the present study (Fig. 1a, Fig. 4a, b). The performance of basal and apical segments of $1.5 \mathrm{~cm}$ was compared in subsequent experiments. In the four clones studied, basal explants produced more and longer shoots than apical explants, resulting in significant differences in the multiplication coefficient and in the number of rootable shoots obtained (Fig. 4c, Fig. 5). However, in relation to leaf parameters, only basal explants of clones C063 and P042 had significantly longer leaves, and only the latter had significantly wider leaves. The positive effect of using basal explants with the attached callus has already been discussed in studies involving chestnut micropropagation in gelled medium (Sánchez et al. 1997). These authors attributed the greater number and length of shoots formed by basal explants to two reasons. First, the longer length of shoots may be related to maintenance of the basal callus, preventing wounding stress and providing a larger area for absorption of nutrients. Second, the larger number of shoots may be due to the release of apical dominance caused by removing the apex, and to the presence of axillary buds at a more advanced stage of development than those of apical sections. It seems that the same features described previously for gelled medium positively influence the development of basal explants in CIS.

Although apical explants could be cultured in CISs, their poor response represented a constraint to the application of the CIS for large-scale propagation, as discarding apical or nodal sections as sources of explant implies loss of a large part of the available plant material. This limitation was partly solved by using larger apical or nodal sections, of about $3 \mathrm{~cm}$, rather than the 1-1.5 cm usually used, and bearing more leaves (Fig. 4d). The results obtained by applying this approach to apical explants of clones C053 and P042 are shown in Table 2. Use of larger explants yielded significantly higher values of all variables measured (except number of shoots in clone C053 and leaf width in clone P042, which reached similar levels in both explants). For clone P042, use of $3 \mathrm{~cm}$-long sections with three-four leaves yielded almost three times the number of segments produced after 5 weeks of culture. Although the proliferation rates were still not as high as in basal explants (see Fig. 5), this procedure allowed more efficient use of the plant material in each subculture. Three-cm long apical and basal sections with leaves were used thereafter for the other genotypes (Fig. 4d). The influence of explant size in micropropagation has already been highlighted by Pierik (1987), who also pointed out that larger explants may be less dependent on the addition of nutrients, including sugars. The use of relatively large shoot explants with leaves has been found to be beneficial for culturing tomato in CIS under photomixotrophic and photoautotrophic conditions (Kubota et al. 2001) as well as for micropropagating potato under photoautotrophic conditions (Miyashita et al. 1996). In this study, the use of $3 \mathrm{~cm}$-long explants was critical for the successful culture of apical sections of chestnut in CIS in photomixotrophic conditions and may help to induce photoautotrophy in chestnut shoots.

\section{Application of CIS to eight chestnut clones}

After completion of the aforementioned experiments, a protocol for culturing chestnut shoots in CIS was established and applied to clones 90025, C003, C042, C053, C063, P028, P042 and P043. Apical and basal 
explants of length $3 \mathrm{~cm}$, with 3-4 expanded leaves, were placed between rockwool cubes in $10 \mathrm{~L}$ bioreactors containing $1 \mathrm{~L}$ of MM. No aeration was provided during the first week of culture, but between weeks two and five, the cultures were aerated for two minutes at a frequency of 16 times every 24 hours. The results are summarized in Table 3. All the clones were successfully propagated in stationary liquid medium, although some differences were detected in relation to genotype. Clone C003 showed the lowest response for all parameters except the percentage of non-hyperhydric shoots and leaf area. Clone C063 was the most proliferative genotype, yielding more and longer shoots, a higher multiplication coefficient and a greater number of rootable shoots than the other clones. Average values of 7.5 for multiplication coefficients, $64 \mathrm{~mm}$ for shoot length, 1.38 for the number of rootable shoots and $254 \mathrm{~mm}^{2}$ for leaf area were obtained. For the six clones that had previously been cultured by TIS (see Table 2 of Vidal et al. 2015a), higher multiplication coefficients and a larger number of rootable shoots were obtained with CIS. Clones C053, C063, P028 and P043 developed longer shoots in CIS, whereas the values of these parameters were similar in both systems for clones 90025 and P042 (Table 3). The findings indicate that CIS may be an efficient method for chestnut micropropagation.

Continuous immersion systems have been used in woody plants with different degrees of success. Culture of apple shoots in a TIS was more successful than culture in a CIS (Chakrabarty et al. 2003). Similar results were reported for Crescentia cujete (Murch et al. 2004), although in this case neither ventilation nor support were applied to shoots cultured in the CIS. However, with Eucalyptus spp. (Nagae et al. 1996, Tanaka et al. 2005), kiwi fruit (Moncaleán et al. 2003), Acacia nilotida (Rathore et al. 2014) and Dalbergia sissoo (Vibha et al. 2014), good results were obtained with continuous immersion of at least the basal section of the explants. Other woody plants, such as Coffea arabusta, Paulownia fortune and Pinus radiata were successfully cultured in a CIS, in large containers with forced ventilation in media with a low sugar content or completely devoid of sugar (to stimulate the photosynthetic ability and photoautotrophic growth) (Nguyen and Kozai 2005). The protocol developed for chestnut, using large vessels with forced aeration could be easily modified in future research to evaluate how this species responds to photoautotrophic conditions.

\section{Leaf area and photosynthetic pigments}

The observed influence of the culture system on the size of leaves and the levels of photosynthetic pigments is summarised in Table 4. Leaves of explants grown in CIS in vented bioreactors were larger than those of explants cultured in SS medium in glass jars $(p<0.001)$, irrespective of the genotype $(p=0.946)$. Larger leaves have been observed in other plants cultured in ventilated vessels, such as Myrtus communis (Lucchesini et al. 2001), Actinidia deliciosa (Arigita et al. 2002), and Pfaffia glomerata (Saldanha et al. 2013). Similarly, Latawa et al. (2016) recently reported that the leaves of hazelnut shoots cultured in liquid medium were larger than those of shoots cultured in semi-solid medium. Leaf growth can be stimulated in vivo by $\mathrm{CO}_{2}$ enrichment (Ferris et al. 2001). Although we did not supply $\mathrm{CO}_{2}$-enriched air to the bioreactors, ambient air entered the vessels during aeration. Kozai and Kubota (2005) reported a positive 
relationship between ventilation with ambient air and the $\mathrm{CO}_{2}$ levels inside the vessels and suggested that the higher availability of $\mathrm{CO}_{2}$ may promote the photosynthetic activity of the explants.

Photosynthetic pigments were significantly influenced by genotype and culture system (Table 4). The levels of all pigments were higher in clone C042 than in clone C053, and explants of both clones cultured in bioreactors had higher levels of chlorophylls and carotenoids than those cultured in jars. Genotypical differences in chlorophyll content have been reported for avocado (Reed et al. 2012) and hazelnut (Latawa et al. 2016). In the latter case, the chlorophyll content was higher in explants cultured in liquid medium by TIS than in those cultured in semi-solid medium. Although Lucchesini et al. (2001) and Hassankhah et al. (2014) reported enhanced chlorophyll contents in shoots of respectively Myrtus communis and Juglans regia cultured in vented containers, Sáez et al. (2012) did not observe any increase in chlorophyll contents of juvenile chestnut shoots cultured in semi-solid medium in vented vessels. However, small containers and natural ventilation were used in the aforementioned study. Forced ventilation has been found to increase the chlorophyll concentration relative to that obtained with natural ventilation or an airtight system in Solanum tuberosum (Cournac et al. 1991) and Brassica oleracea (Zobayed et al. 1999). The chlorophyll contents of both Rehmannia glutinosa (Cui et al. 2000) and Pfaffia glomerata (Saldanha et al. 2012) increased significantly in response to an increase in the frequency of air exchange in the vessel.

Enhancing the photosynthetic ability of plants in vitro may improve growth conditions and favour the success of further acclimatization to ex vitro conditions (Kozai, 1991). Although the chlorophyll content by itself may not reflect the photosynthetic ability of plantlets (Fujiwara et al. 1992), the larger leaves obtained in chestnut explants cultured in a CIS may be helpful during the transition to autotrophic conditions at the rooting and acclimatization stages (Aragón et al. 2005).

\section{Rooting and acclimatization}

Vigorous shoots of clones C042 and C053 cultured in the CIS were treated with IBA and inoculated ex vitro into 3 types of substrates (Fig. 6a). All substrates were plugs of porous material such as rockwool or peat, either mixed with bark and plant-derived bio-degradable polymers (Root! $t^{\circledR}$ ) or surrounded by fine netting (Jiffy ${ }^{\circledR}$ pots). Four weeks after auxin treatment, shoots with roots emerging from the plugs were transferred to pots (Fig. 6b, c, d). Eight weeks after IBA treatment, the number of acclimated shoots was recorded (Fig. 7). The highest percentages of acclimated shoots were obtained with rockwool cubes for clone C042 (73\%) and with Root! ${ }^{\circledR}$ sponges for clone C053 (69\%). Chestnut is difficult to root and the rooted plantlets often do not survive the process of adaptation to ex vitro conditions (Gonçalves et al. 1998; Carvalho and Amâncio 2002; Vieitez et al. 2007; Sáez et al. 2015). However, shoots grown in CIS regrew quickly after IBA treatment, indicating a healthy physiological state (Fig. 6e). Shoots rooted in the commercial plugs were easily transferred to pots (Fig. 6f) and continued to grow in the greenhouse (Fig. $6 \mathrm{~g})$. The use of fibrous or porous support materials was shown to be beneficial for difficult-to-root woody plants (Kozai and Kubota 2001). Maner and Merkle (2010) compared the use of peat Flexiplugs ${ }^{\circledR}$ (similar to the Root! $\mathrm{t}^{\circledast}$ plugs used here) and of agar for germinating somatic embryos of American chestnut. Roots 
emerging in the plugs were of better quality and the plants required much less handling to transfer them to ex vitro conditions than plants whose roots formed on gelled medium. Transplanting plants along with the support material reduces the possibility of root damage and enables automated handling as in plug seedling production (Kozai and Kubota 2001).

In summary, chestnut axillary shoots were micropropagated for the first time by continuous immersion in liquid medium in large vessels. The use of some type of support material and supply of fresh air by forced aeration were essential for preventing hyperhydricity, a disorder associated with liquid culture (Etienne and Berthouly 2002). Apical and basal sections of eight selected genotypes were able to be cultured efficiently after optimization of parameters such as bioreactor size, support material, explant size and aeration regime. Basal sections displayed high proliferation rates and yielded good quality shoots suitable for multiplication, rooting and acclimatization. Shoots cultured in the CIS had larger leaves and more photosynthetic pigments than those cultured by conventional micropropagation in smaller flasks with agar and without ventilation, suggesting that the CIS induced a certain degree of photoautotrophy. The use of large vessels and forced aeration, as proposed here, may enable manipulation of the inner gaseous atmosphere of bioreactors in future studies, thereby allowing exploration of the photoautotrophic micropropagation of this species.

\section{References}

Aragón CE, Escalona M, Capote I, Pina D, Cejas I, Rodríguez R, Cañal MJ, Sandoval J, Roels S, Debergh P, González-Olmedo JL (2005) Photosynthesis and carbon metabolism in plantain (Musa AAB) growing in temporary immersion bioreactor (TIB) and ex vitro acclimatization. In Vitro Cell Dev Biol Plant 41: 550-554. doi: 10.1079/IVP2005640

Arigita L, González A, Sánchez Tamés R (2002) Influence of $\mathrm{CO}_{2}$ and sucrose on photosynthesis and transpiration of Actinidia deliciosa explants cultured in vitro. Physiol Plant 115: 166-173. doi:10.1034/j.1399-3054.2002.1150119.x

Carvalho L, Amâncio S (2002) Effect of ex vitro conditions on growth and acquisition of autotrophic behaviour during the acclimatization of chestnut regenerated in vitro. Sci Hort 95:151-164. doi: 10.1016/S0304-4238(02)00037-7

Chakrabarty D, Dewir YH, Hahn EJ, Datta SK, Paek KY (2007) The dynamics of nutrient utilization and growth of apple root stock 'M9 EMLA' in temporary versus continuous immersion bioreactors. Plant Growth Regul 51:11-19. doi:10.1007/s10725-006-9115-5

Chakrabarty D, Hahn EJ, Yoon YS, Paek KY (2003) Micropropagation of apple root stock M9 EMLA using bioreactor. J Hortic Sci Biotechnol 78:605-609. doi:10.1080/14620316.2003.11511671

Cournac L, Dimon B, Carrier P, Lohou A, Chagvardieff P (1991) Growth and photosynthetic characteristics of Solanum tuberosum plantlets cultivated in vitro in different conditions of aeration, sucrose supply and $\mathrm{CO}_{2}$ enrichment. Plant Physiol 97:112-117. doi:10.1104/pp.97.1.112

Cui Y, Hahn E, Kozai T, Paek K (2000) Number of air exchanges, sucrose concentration, photosynthetic photon flux, and differences in photoperiod and dark period temperatures affect growth of 
Rehmannia glutinosa plantlets in vitro. Plant Cell Tiss Organ Cult 62: 219-226. doi: 10.1023/A:1006412321864

Dimasi-Theriou K, Economou AS (1995) Ethylene enhances shoot formation in cultures of the peach rootstock GF-677 (Prunus persica x P. amygdalus). Plant Cell Rep 15:87-90. doi: 10.1007/BF01690260

Ermayanti TM, Imelda M, Tajuddin T, Kubota C, Kozai T (1999) Growth promotion by controlling in vitro environment in micropropagation of tropical plant species. Proc. The Tokyo Intl. Forum on Conservation and Sustainable Use of Tropical Bioresources. pp 10-25. NEDO and IBA, Tokyo.

Etienne H, Berthouly M (2002) Temporary immersion systems in plant micropropagation. Plant Cell Tiss Organ Cult 69: 215-231. doi: 10.1023/A:1015668610465

Feito I, González A, Centeno M, Fernández B, Rodríguez A (2001) Transport and distribution of benzyladenine in Actinidia deliciosa explants cultured in liquid and solid media. Plant Physiol Biochem 39:909-916. doi: 10.1016/S0981-9428(01)01309-2

Ferris R, Sabatti M, Miglietta F, Mills RF, Taylor G (2001) Leaf area is stimulated in Populus by free air CO2 enrichment (POPFACE), through increased cell expansion and production. Plant Cell Environ 24:305315. doi: 10.1046/j.1365-3040.2001.00684.x

Fujiwara K, Kira S, Kozai T (1992) Time course of $\mathrm{CO}_{2}$ exchange of potato cultures in vitro with different sucrose concentrations in the culture medium. J Agr Met 48:49-56

Goel MK, Kukreja AK, Bisht NS (2009) In vitro manipulations in St. John's wort (Hypericum perforatum L.) for incessant and scale up micropropagation using adventitious roots in liquid medium and assessment of clonal fidelity using RAPD analysis. Plant Cell Tiss Organ Cult 96:1-9. doi $10.1007 / \mathrm{s} 11240-008-9453-2$

Goel MK, Kukreja AK, Khanuja SPS (2007) Cost-effective approaches for in vitro mass propagation of Rauwolfia serpentina Benth. Ex Kurz Asian J Plant Sci 6:957-961. doi: 10.3923/ajps.2007.957.961

González A, Arigita L, Majada J, Sánchez Tamés R (1997) Ethylene involvement in in vitro organogenesis and plant growth of Populus tremula L. Plant Growth Regul 22:1-6. doi: 10.1023/A:1005751017498

González MV, Cuenca B, López M, Prado MJ, Rey M (2011) Molecular characterization of chestnut plants selected for putative resistance to Phytophthora cinnamomi using SSR markers. Sci Hortic 130:459467. doi: 10.1016/j.scienta.2011.07.020

Gonçalves JC, Diogo G, Amâncio S (1998) In vitro propagation of chestnut (Castanea sativa X C. crenata): Effects of rooting treatments on plant survival, peroxidase activity and anatomical changes during adventitious root formation. Sci. Hort. 72:265-275. doi: 10.1016/S0304-4238(97)00136-2

Hassankhah A, Vahdati K, Lotfi M, Mirmasoumi M, Preece J, Assareh M-H (2014) Effects of ventilation and sucrose concentrations on the growth and plantlet anatomy of micropropagated Persian walnut plants. Int J Hortic Sci Technol 1:111-120.

Kiferle C, Lucchesini M, Maggini R, Pardossi A, Mensuali-Sodi A (2014) In vitro culture of sweet basil: gas exchanges, growth and rosmarinic acid production. Biol Plant 58:601-610. doi: 10.1007/s10535-0140434-5 
Kirdmanee C, Kitaya Y, Kozai T (1995) Effects of $\mathrm{CO}_{2}$ enrichment and supporting material in vitro on photoautotrophic growth of Eucalyptus plantlets in vitro and ex vitro. In Vitro Cell Dev Biol Plant 31:144-149. doi: 10.1007/BF02632010

Kozai T (1991) Photoautotrophic micropropagation. In Vitro Cell Dev Biol Plant 27:47-51. doi: 10.1007/BF02632127

Kozai T, Kubota C (2001) Developing a photoautotrophic micropropagation system for woody plants. J Plant Res 114:525-537. doi: 10.1007/PL00014020

Kozai T, Kubota C (2005) In vitro aerial environments and their effects on growth and development of plants. In T. Kozai et al. (eds.) Photoautotrophic (sugar-free medium) micropropagation as a new propagation and transplant production system. Springer, The Netherlands, pp 31-52

Kubota C, Kakizaki N, Kozai T, Kasahara K, Nemoto J (2001) Growth and net photosynthetic rate of tomato plantlets during photoautotrophic and photomixotrophic micropropagation. Hort. Sci. 36:49-52

Lai CC, Lin HM, Nalawade SM, Fang W, Tsay HS (2005) Hyperhydricity in shoot cultures of Scrophularia yoshimurae can be effectively reduced by ventilation of culture vessels. J. Plant Physiol 162:355-361. doi: 10.1016/j.jplph.2004.07.015

Latawa Y, Shukla MR, Saxena PK (2016) An efficient temporary immersion system for micropropagation of hybrid hazelnut. Botany 94:1-8. doi: 10.1139/cjb-2015-0111

Lucchesini M, Mensuali-Sodi A, Massai R, Gucci R (2001) Development of autotrophy and tolerance to acclimatization of Myrtus communis transplants cultured in vitro under different aeration. Biol Plant 44:167-174. doi: 10.1023/A:1010277403705

Maner L, Merkle S (2010) Polymerized peat plugs improve American chestnut somatic embryo germination in vitro. J American Chestnut Foundation 24(3):16

Mingozzi M, Montello P, Merkle S (2009) Adventitious shoot regeneration from leaf explants of eastern cottonwood (Populus deltoides) cultured under photoautotrophic conditions. Tree Physiol 29:333343. doi:10.1093/treephys/tpn029

Miyashita Y, Kitaya Y, Kubota C, Kozai T (1996) Photoautotrophic growth of potato plantlets as affected by explant leaf area, fresh weight and stem length. Sci Hortic 65:199-202. doi: 10.1016/03044238(96)00877-1

Moncaleán P, Cañal MJ, Feito I, Rodríguez A, Fernández B (1999) Cytokinins and mineral nutrition in Actinidia deliciosa shoots cultured in vitro. J Plant Physiol 155:606-612. doi: 10.1016/S01761617(99)80061-3

Moncaleán P, Cañal MJ, Fernández H, Fernández B, Rodríguez A (2003) Nutritional and gibberellic acid requirements in kiwifruit vitroponic cultures. In Vitro Cell Dev Biol Plant 39:49-55. doi:10.1079/IVP2002371

Mosaleeyanon K, Cha-um S, Kirdmanee C (2004) Enhanced growth and photosynthesis of rain tree (Samanea saman Merr.) plantlets in vitro under a $\mathrm{CO}_{2}$-enriched condition with decreased sucrose concentrations in the medium. Sci Hortic 103:51-63. doi:10.1016/j.scienta.2004.02.010 
Murashige T, Skoog F (1962) A revised medium for rapid growth and bioassays with tobacco tissue culture. Physiol Plant 15:473-497. doi: 10.1111/j.1399-3054.1962.tb08052.x

Murch SJ, Chunzhao L, Romero RM, Saxena PK (2004) In vitro culture and temporary immersion bioreactor production of Crescentia cujete. Plant Cell Tiss Organ Cult 78:36-68. doi: 10.1023/B:TICU.0000020397.01895.3e

Nagae S, Takamura T, Watanabe T, Murakami A, Murakami K, Tanaka M (1996) In vitro shoot development of Eucalyptus citriodora on rockwool in the film culture vessel under $\mathrm{CO}_{2}$ enrichment. J For Res 1:227230 doi: $10.1007 / B F 02348330$

Nguyen QT, Kozai T (2001) Photoautotrophic micropropagation of tropical and subtropical woody plants. In: Molecular Breeding of Woody Plants. Eds. N Morohoshi and A Komamine. Elsevier Science B V, Amsterdam, The Netherlands. pp 335-344

Nguyen QT, Kozai T (2005) Photoautotrophic micropropagation of woody species. In T. Kozai et al. (eds.), Photoautotrophic (sugar-free medium) micropropagation as a new propagation and transplant production system. Springer, The Netherlands, pp 123-146

Nguyen QT, Kozai T, Heo J, Thai DX (2001) Photoautotrophic growth response of in vitro cultured coffee plantlets to ventilation methods and photosynthetic photon fluxes under carbon dioxide enriched condition. Plant Cell Tiss Org Cult 66:217-225. doi: 10.1023/A:1010662413486

Nguyen QT, Xiao Y, Kozai T (2016) Photoautotrophic Micropropagation. In: Plant Factory - An indoor vertical farming system for efficient quality food production, Edition: 1st, Chapter: 20, Publisher: Elsevier, Academic Press, United Kingdom, Editors: Toyoki Kozai, Genhua Niu, Michiko Takagaki, pp.271-283. doi: 10.1016/B978-0-12-801775-3.00020-2

Norikane A, Takamura T, Morokuma M, Tanaka M (2010) In vitro growth and single-leaf photosynthetic response of Cymbidium plantlets to super-elevated $\mathrm{CO}_{2}$ under cold cathode fluorescent lamps. Plant Cell Rep 29:273-383. doi: 10.1007/s00299-010-0820-1

Norikane A, Teixeira da Silva JA, Tanaka M (2013) Growth of in vitro Oncidesa plantlets cultured under cold cathode fluorescent lamps (CCFLs) with super-elevated $\mathrm{CO}_{2}$ enrichment. AoB PLANTS 5: plt044. doi:10.1093/aobpla/plt044

Nour KA, Thorpe TA (1994) The effect of the gaseous state on bud induction and shoot multiplication in vitro in eastern white cedar. Physiol Plant 90:163-172. doi: 10.1111/j.1399-3054.1994.tb02207.x

Petrova M, Zayova E, Todorova M, Stanilova M (2014) Enhancement of Arnica montana in vitro shoot multiplication and sesquiterpene lactones production using temporary immersion system. IJPSR 5: 5170-5176. doi: 10.13040/IJPSR.0975-8232.5 (12).5170-76

Pierik RLM (1987) The influence of plant material on growth and development. In: In Vitro Culture of Higher Plants. Martinus Nijhoff Publishers, Dordrecht, pp. 107-114

Preece JE (2010) Micropropagation in stationary liquid media. Propag Ornam Plants 10:183-187

Rathore JS, Rai MK, Phulwaria M, Shekhawat NS (2014) A liquid culture system for improved micropropagation of mature Acacia nilotica (L.) Del. ssp. indica and ex vitro rooting. Proc Natl Acad Sci India Sect B Biol Sci 84:193-200. doi: 10.1007/s40011-013-0204-8 
Reed S, Schnell R, Moore J M, Dunn C (2012) Chlorophyll a + b content and chlorophyll fluorescence in avocado. J Agric Sci 4:29-36. doi: 10.5539/jas.v4n4p29

Rojas-Martínez L, Visser RGF, de Klerk G-J (2010) The hyperhydricity syndrome: waterlogging of plant tissues as a major cause. Propag Ornam Plants 10: 169-175

Sáez P, Bravo L, Latsague M, Sanchez-Olate M, Ríos D (2012) Increased light intensity during in vitro culture improves water loss control and photosynthetic performance of Castanea sativa grown in ventilated vessels. Sci Hortic 130:7-16. doi:10.1016/j.scienta.2012.02.005

Sáez PL, Bravo LA, Latsague MI, Toneatti MJ, Coopman RE, Álvarez CE, Sánchez-Olate M, Ríos DG (2015) Influence of in vitro growth conditions on the photosynthesis and survival of Castanea sativa plantlets during ex vitro transfer. Plant Growth Regul 75:625-639. doi 10.1007/s10725-014-9965-1

Saldanha CW, Otoni CG, Azevedo JLF, Dias LLC, Rêgo MM, Otoni WC (2012) A low-cost alternative membrane system that promotes growth in nodal cultures of Brazilian ginseng [Pfaffia glomerata (Spreng.) Pedersen]. Plant Cell Tiss Org Cult 110:413-422. doi 10.1007/s11240-012-0162-5

Saldanha CW, Otoni CG, Notini MM, Kuki KN, Cruz ACF, Rubio Neto A, Dias LLC, Otoni WC (2013) A CO2enriched atmosphere improves in vitro growth of Brazilian ginseng [Pfaffia glomerata (Spreng.) Pedersen]. In Vitro Cell Dev Biol Plant 49:433-444. doi: 10.1007/s11627-013-9529-5

Sánchez MC, San-José MC, Ferro E, Ballester A, Vieitez AM (1997) Improving micropropagation conditions for adult-phase shoots of chestnut. J Hortic Sci 72:433-443. doi: 10.1080/14620316.1997.11515531

Savio LEB, Astarita LV, Santarém ER (2012) Secondary metabolism in micropropagated Hypericum perforatum L. grown in non-aerated liquid medium. Plant Cell Tiss Organ Cult 108:465-472. doi:10.1007/s11240-011-0058-9

Tanaka M, Giang DTT, Murakami A (2005). Application of a novel disposable film culture system to photoautotrophic micropropagation of Eucalyptus uro-grandis (Urophylia x grandis). In Vitro Cell Dev Biol Plant 41:173-180. doi: 10.1079/IVP2004622

Tanaka M, Nagae S, Fukai S, Goi M (1992) Growth of tissue cultured Spathiphyllum on rockwool in a novel film culture vessel under high $\mathrm{CO}_{2}$. Acta Hortic 314:139-146. doi: 10.17660/ActaHortic.1992.314.16

Thorpe T, Stasolla C, Yeung EC, De Klerk GJ, Roberts A, George EF (2008) The components of plant tissue culture media II: organic additions, osmotic and pH effects, and support systems. In: George EF, Hall MA, De Klerk GJ (eds) Plant propagation by tissue culture, volume 1. The background, 3ㅇ edn. Springer,Dordrecht, pp 115-173

Troch V, Sapeta H, Werbrouck S, Geelen D, Van Labeke MC (2010) In vitro culture of chestnut (Castanea sativa Mill.) using temporary immersion bioreactors. Acta Hortic 885:383-390. doi: 10.17660/ActaHortic.2010.885.54

Vibha JB, Shekhawat NS, Mehandru P, Dinesh R (2014) Rapid multiplication of Dalbergia sissoo Roxb.: a timber yielding tree legume through axillary shoot proliferation and ex vitro rooting. Physiol Mol Biol Plant 20:81-87. doi: 10.1007/s12298-013-0213-3 
Vidal N, Blanco B, Cuenca B (2015a) A temporary immersion system for micropropagation of axillary shoots of hybrid chestnut. Plant Cell Tissue Organ Cult 123:229-243. doi: 10.1007/s11240-015-0827y

Vidal N, Correa B, Rial E, Regueira M, Sánchez C, Cuenca B (2015b) Comparison of temporary and continuous immersion systems for micropropagation of axillary shoots of chestnut and willow. Acta Hortic 1083:227-233. doi: 10.17660/ActaHortic.2015.1083.27

Vidal N, Vieitez AM, Fernández MR, Cuenca B, Ballester A (2010) Establishment of cryopreserved gene banks of European chestnut and cork oak. Eur J Forest Res 129: 635-643. doi: 10.1007/s10342-0100364-5

Vieitez AM, Ballester A, San José MC, Vieitez E (1985) Anatomical and chemical studies of vitrified shoots of chestnut regenerated in vitro. Physiol Plant 65:177-184. doi:10.1111/j.1399-3054.1985.tb02379.x

Vieitez AM, Sánchez MC, García-Nimo ML, Ballester A (2007) Protocol for micropropagation of Castanea sativa Mill. In: SM Jain and H Häggman (eds.), Protocols for micropropagation of woody trees and fruits. Springer, Heidelberg, pp 299-312

Wellburn AR (1994). The spectral determination of chlorophylls a and b, as well as total carotenoids, using various solvents with spectrophotometers of different resolution. J Plant Physiol 144:307-313. doi: 10.1016/S0176-1617(11)81192-2

Xiao Y, Niu G, Kozai T (2011) Development and application of photoautotrophic micropropagation plant system. Plant Cell Tiss Organ Cult 105:149-158. doi: 10.1007/s11240-010-9863-9

Xiao Y, Zhao J, Kozai T (2000) Practical sugar-free micropropagation system using large vessels with forced ventilation. In: Transplant Production in the 21st Century. Eds. C. Kubota and C. Chun. Kluwer Academic Publishers, The Netherlands, pp 266-273

Zobayed SMA (2005) Ventilation in micropropagation. In T. Kozai et al. (eds.), Photoautotrophic (sugarfree medium) micropropagation as a new propagation and transplant production system. Springer, The Netherlands, pp 147-186

Zobayed SMA, Afreen-Zobayed F, Kubota C and Kozai T (2000) Mass propagation of Eucalyptus camaldulensis in a scaled-up vessel under in vitro photoautotrophic condition. Ann Bot 85:587-592. doi: 10.1006/anbo.1999.1106

Zobayed SMA, Armstrong J, Armstrong W (1999) Cauliflower shoot-culture: effects of different types of ventilation on growth and physiology. Plant Sci 141:209-217. doi: 10.1016/S0168-9452(98)00232-5 
Table 1. Proliferation rates and shoot quality of basal explants of clones C063 and P028 cultured in 1 or $10 \mathrm{~L}$ containers. The explants were placed between rockwool cubes and cultured for 5 weeks with aeration for two minutes 16 times per day.

3

\begin{tabular}{|c|c|c|c|c|c|c|c|c|c|c|}
\hline Clone & $\begin{array}{l}\text { Volume } \\
\text { of } \\
\text { container }\end{array}$ & $\begin{array}{c}\text { Volume of } \\
\text { medium/explant } \\
(\mathrm{mL})\end{array}$ & $\% \mathrm{NE}$ & NS & $\mathrm{SL}(\mathrm{mm})$ & $\mathrm{MC}$ & RS & $\mathrm{LL}(\mathrm{mm})$ & LW (mm) & $\mathrm{LA}\left(\mathrm{mm}^{2}\right)$ \\
\hline \multirow[t]{2}{*}{$\mathrm{C063}$} & $1 \mathrm{~L}$ & 12.5 & $81 \pm 5.6 a$ & $4.7 \pm 0.35 b$ & $41.4 \pm 2.91 b$ & $6.1 \pm 0.47 b$ & $0.46 \pm 0.07 b$ & $21.4 \pm 1.79 \mathrm{~b}$ & $6.6 \pm 0.64 a$ & $220 \pm 62.7 \mathrm{a}$ \\
\hline & $10 \mathrm{~L}$ & 27.8 & $83 \pm 5.6 a$ & $7.2 \pm 0.43 a$ & $62.3 \pm 4.29 a$ & $11.0 \pm 0.71 \mathrm{a}$ & $1.64 \pm 0.18 a$ & $29.6 \pm 1.99 a$ & $7.6 \pm 0.60 a$ & $280 \pm 64.9 a$ \\
\hline \multirow[t]{2}{*}{$\mathrm{P} 028$} & $1 \mathrm{~L}$ & 12.5 & $88 \pm 5.6 a$ & $2.6 \pm 0.16 a$ & $40.4 \pm 2.64 \mathrm{a}$ & $4.1 \pm 0.26 a$ & $0.97 \pm 0.05 a$ & $32.7 \pm 1.43 a$ & $8.5 \pm 0.42 a$ & $336 \pm 75.1 \mathrm{a}$ \\
\hline & $10 \mathrm{~L}$ & 27.8 & $86 \pm 5.6 a$ & $2.4 \pm 0.24 a$ & $45.7 \pm 4.46 a$ & $4.2 \pm 0.37 a$ & $0.81 \pm 0.10 a$ & $31.6 \pm 2.46 a$ & $9.5 \pm 1.01 \mathrm{a}$ & $611 \pm 205.7 a$ \\
\hline
\end{tabular}

4

Values represent the mean \pm standard error from 3 replicates of 12 shoots each. For each clone and variable, different letters indicate significant differences at $P<0.05$.

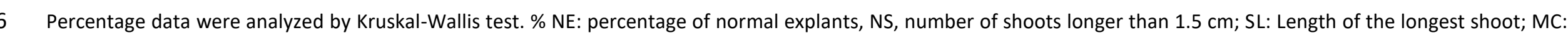

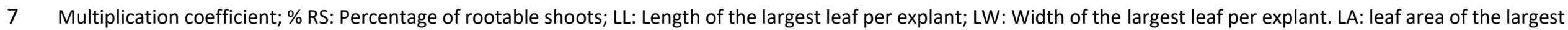

8 leaf per explant. 
Table 2. Effect of explant size $(1.5$ or $3 \mathrm{~cm})$ on the growth response of apical sections of chestnut clones C053 and P042 cultured in CIS with rockwool cubes.

\begin{tabular}{|c|c|c|c|c|c|c|c|}
\hline Clone & $\begin{array}{l}\text { Explant } \\
\text { size }\end{array}$ & NS & $\mathrm{SL}(\mathrm{mm})$ & $\mathrm{MC}$ & RS & $\mathrm{LL}(\mathrm{mm})$ & LW (mm) \\
\hline \multirow[t]{2}{*}{ C053 } & $1.5 \mathrm{~cm}$ & $1.2 \pm 0.11 a$ & $26.4 \pm 1.81 b$ & $2.7 \pm 0.28 b$ & $0.08 \pm 0.08 b$ & $17.9 \pm 1.52 b$ & $5.7 \pm 0.31 b$ \\
\hline & $3 \mathrm{~cm}$ & $1.0 \pm 0.01 \mathrm{a}$ & $53.9 \pm 3.24 a$ & $4.0 \pm 0.34 a$ & $1.0 \pm 0.09 a$ & $33.6 \pm 2.28 a$ & $11.8 \pm 0.93 a$ \\
\hline \multirow[t]{2}{*}{ P042 } & $1.5 \mathrm{~cm}$ & $1.1 \pm 0.05 b$ & $25.0 \pm 1.35 b$ & $1.3 \pm 0.08 b$ & $0.11 \pm 0.05 b$ & $24.4 \pm 1.17 b$ & $9.8 \pm 0.48 a$ \\
\hline & $3 \mathrm{~cm}$ & $1.6 \pm 0.14 a$ & $44.6 \pm 2.35 \mathrm{a}$ & $3.7 \pm 0.22 \mathrm{a}$ & $0.53 \pm 0.08 a$ & $28.9 \pm 1.31 \mathrm{a}$ & $10.8 \pm 0.48 a$ \\
\hline
\end{tabular}

Values represent the mean \pm standard error from 3 replicates of 12 shoots each. For each variable, different letters indicate significant differences at $P<0.05$. NS, number of shoots longer than $1.5 \mathrm{~cm}$; SL: Length of the longest shoot; MC: Multiplication coefficient; RS: number of rootable shoots per explant; LL: Length of the largest leaf per explant; LW: Width of the largest leaf per explant.

Table 3. Proliferation of basal sections of 8 chestnut clones cultured in $\mathrm{C} 10$ bioreactors. The explants were placed between rockwool cubes and cultured for one week without aeration followed by four weeks with aeration for two minutes 16 times per day.

\begin{tabular}{ccccccc}
\hline Clone & $\% \mathrm{NE}$ & $\mathrm{NS}$ & $\mathrm{SL}(\mathrm{mm})$ & $\mathrm{MC}$ & $\mathrm{RS}$ & $\mathrm{LA}\left(\mathrm{mm}^{2}\right)$ \\
& & & & & & \\
\hline 90025 & $88 \pm 4.8 \mathrm{ab}$ & $3.8 \pm 0.30 \mathrm{~b}$ & $65.4 \pm 3.78 \mathrm{~b}$ & $8.1 \pm 0.56 \mathrm{~b}$ & $1.08 \pm 0.11 \mathrm{de}$ & $295 \pm 30.9 \mathrm{ab}$ \\
$\mathrm{C} 003$ & $100 \pm 0.0 \mathrm{a}$ & $1.2 \pm 0.07 \mathrm{~d}$ & $48.0 \pm 4.58 \mathrm{c}$ & $2.7 \pm 0.24 \mathrm{c}$ & $0.66 \pm 0.09 \mathrm{e}$ & $350 \pm 35.7 \mathrm{a}$ \\
$\mathrm{C} 042$ & $100 \pm 0.0 \mathrm{a}$ & $1.3 \pm 0.09 \mathrm{~d}$ & $55.0 \pm 2.80 \mathrm{bc}$ & $5.9 \pm 0.61 \mathrm{~b}$ & $1.21 \pm 0.09 \mathrm{cde}$ & $264 \pm 24.0 \mathrm{abc}$ \\
$\mathrm{C} 053$ & $100 \pm 0.0 \mathrm{a}$ & $2.4 \pm 0.20 \mathrm{c}$ & $67.4 \pm 3.94 \mathrm{~b}$ & $8.1 \pm 0.76 \mathrm{~b}$ & $1.73 \pm 0.15 \mathrm{~b}$ & $201 \pm 17.5 \mathrm{bc}$ \\
$\mathrm{C} 063$ & $96 \pm 3.1 \mathrm{a}$ & $8.1 \pm 0.48 \mathrm{a}$ & $95.4 \pm 3.73 \mathrm{a}$ & $14.6 \pm 0.76 \mathrm{a}$ & $2.47 \pm 0.19 \mathrm{a}$ & $219 \pm 27.4 \mathrm{bc}$ \\
$\mathrm{P} 028$ & $85 \pm 5.8 \mathrm{~b}$ & $2.5 \pm 0.21 \mathrm{c}$ & $59.3 \pm 3.16 \mathrm{bc}$ & $6.5 \pm 0.52 \mathrm{~b}$ & $1.24 \pm 0.14 \mathrm{~cd}$ & $164 \pm 16.1 \mathrm{c}$ \\
$\mathrm{P} 042$ & $100 \pm 0.0 \mathrm{a}$ & $2.6 \pm 0.26 \mathrm{c}$ & $57.2 \pm 3.63 \mathrm{bc}$ & $6.3 \pm 0.53 \mathrm{~b}$ & $1.46 \pm 0.18 \mathrm{~cd}$ & $174 \pm 20.9 \mathrm{bc}$ \\
$\mathrm{P} 043$ & $100 \pm 0.0 \mathrm{a}$ & $3.2 \pm 0.17 \mathrm{bc}$ & $62.2 \pm 3.06 \mathrm{bc}$ & $6.6 \pm 0.48 \mathrm{~b}$ & $1.27 \pm 0.18 \mathrm{~cd}$ & $374 \pm 48.7 \mathrm{a}$ \\
\hline
\end{tabular}

Values represent the mean \pm standard error from 3 replicates of 12 shoots each For each variable, different letters indicate significant differences at $\mathrm{P}<0.05$. Percentage data were analyzed by KruskalWallis test. \% NE: percentage of normal explants, NS, number of shoots longer than $1.5 \mathrm{~cm}$; SL: Length of the longest shoot; MC: Multiplication coefficient; \% RS: number of rootable shoots per explant; LA: Area of the largest leaf per explant. 
Table 4. Effect of culture system and genotype on leaf parameters of chestnut clones C042 and C053. Explants were cultured in semi-solid medium (SS) and in liquid medium in a continuous immersion system (CIS) and the two uppermost leaves were collected for analysis.

\begin{tabular}{clcccc}
\hline Clone & $\begin{array}{c}\text { Culture } \\
\text { system }\end{array}$ & LA $\left(\mathrm{mm}^{2}\right)$ & $\begin{array}{c}\text { Chlor a } \\
(\mu \mathrm{g} / \mathrm{g} \mathrm{FW})\end{array}$ & $\begin{array}{c}\text { Chlor b } \\
(\mu \mathrm{g} / \mathrm{g} \mathrm{FW})\end{array}$ & $\begin{array}{c}\text { Carotenoids } \\
(\mu \mathrm{g} / \mathrm{g} \mathrm{FW})\end{array}$ \\
\hline $\mathrm{C042}$ & $\mathrm{SS}$ & $36 \pm 9.2 \mathrm{Ab}$ & $870 \pm 138 \mathrm{Ab}$ & $548 \pm 96 \mathrm{Ab}$ & $253 \pm 30 \mathrm{Ab}$ \\
& $\mathrm{CIS}$ & $186 \pm 26.6 \mathrm{Aa}$ & $1141 \pm 40 \mathrm{Aa}$ & $753 \pm 43 \mathrm{Aa}$ & $327 \pm 17 \mathrm{Aa}$ \\
\hline $\mathrm{C053}$ & $\mathrm{SS}$ & $45 \pm 9.6 \mathrm{Ab}$ & $575 \pm 31 \mathrm{Bb}$ & $302 \pm 20 \mathrm{Bb}$ & $183 \pm 8 \mathrm{Bb}$ \\
& $\mathrm{CIS}$ & $180 \pm 16.1 \mathrm{Aa}$ & $1010 \pm 61 \mathrm{Ba}$ & $622 \pm 55 \mathrm{Ba}$ & $294 \pm 20 \mathrm{Ba}$ \\
\hline
\end{tabular}

Values represent the mean \pm standard error from 3 replicates of 12 shoots each. For each variable, different capital letters indicate significant differences regarding chestnut genotype, and different lowercase letters indicate significant differences in relation to the culture system. $P<0.05$. LA: leaf area of the largest leaf per explant. Chlor: chlorophyll. FW: Fresh weight. 
Figures:

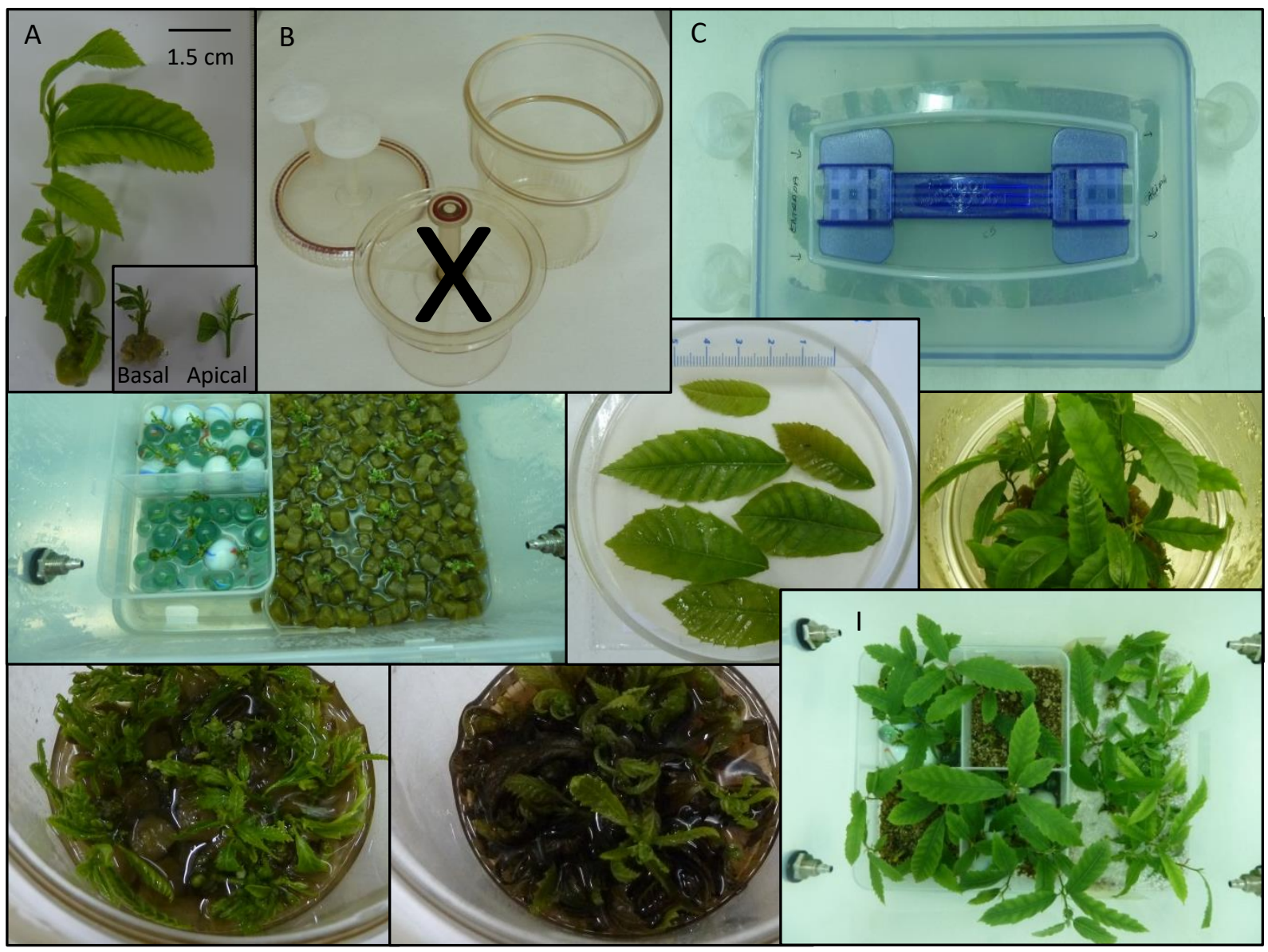

Fig. 1 A) Chestnut shoot used for initial experiments in the continuous immersion system (CIS). In the box, basal and apical sections of $1.5 \mathrm{~cm}$. B-D) Containers used in CIS: (B) RITA ${ }^{\circledR}$ vessels without inner basket and (C D) Lock \& Lock $^{\circledR}$ food containers adapted in the laboratory; E) Leaves of clone C042 used for pigment quantitation; F-H) Basal explants of clone 90025 after 5 weeks of culture in RITA ${ }^{\circledR}$ vessels: $(F, G)$ explants placed between rockwool cubes and $(F)$ provided or $(G)$ not with forced aeration 16 times per day, H) Explants cultured without rockwool cubes and with forced aeration; and I) Basal explants of clone 90025 cultured in $10 \mathrm{~L}$ containers with perlite, vermiculite or glass beads as substrate 


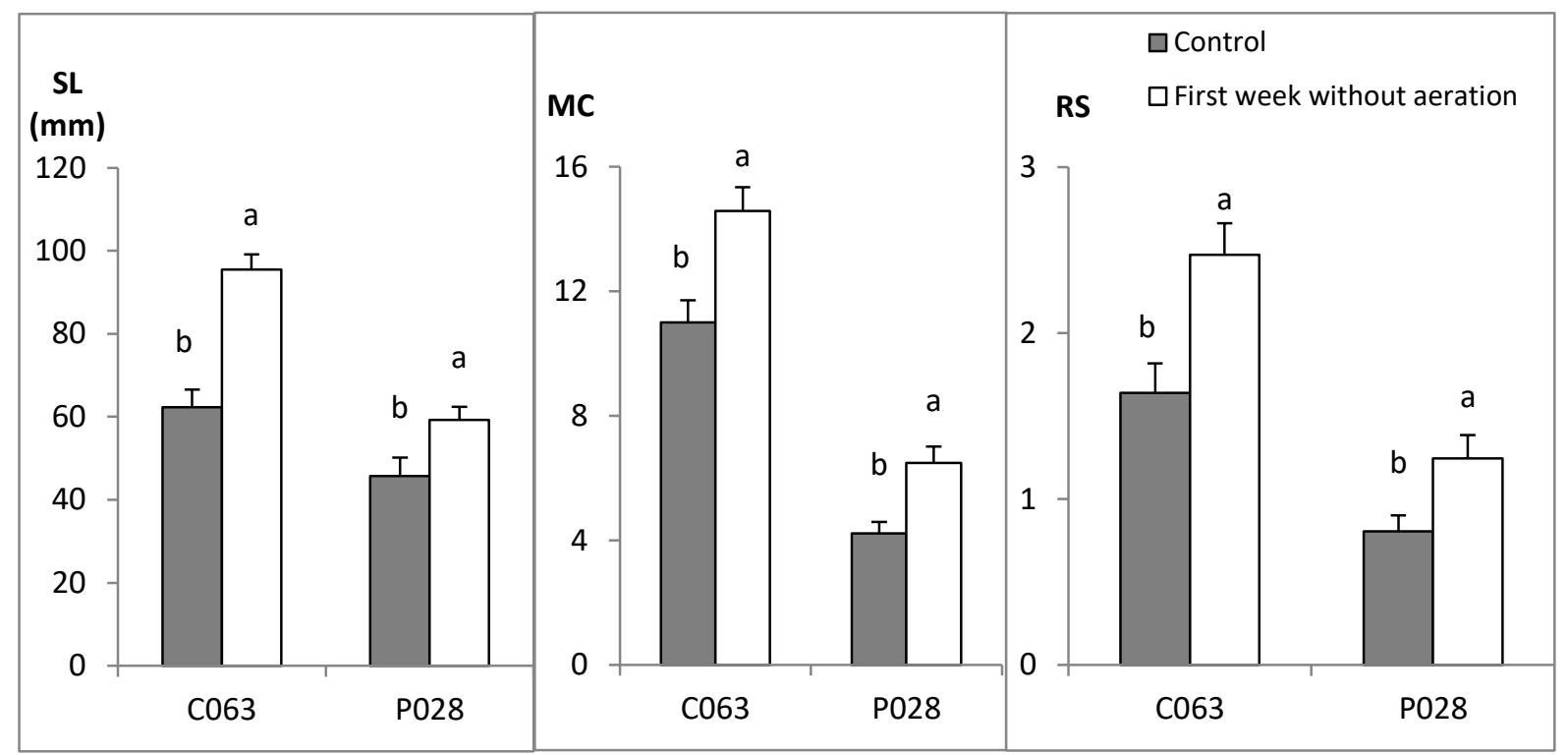

Fig. 2 Shoot length (SL), multiplication coefficient (MC), and number of rootable shoots (RS) of basal explants of clones $\mathrm{C} 063$ and P028 cultured in $10 \mathrm{~L}$ containers and subjected to different aeration regimes. The explants were placed between rockwool cubes and cultured for 5 weeks with aeration for two minutes 16 times per day (control) or were not provided aeration during the first week of culture. Values represent the mean \pm standard error from 3 replicates of 12 shoots each. For each clone, different letters indicate significant differences at $\mathrm{P}<0.05$ 


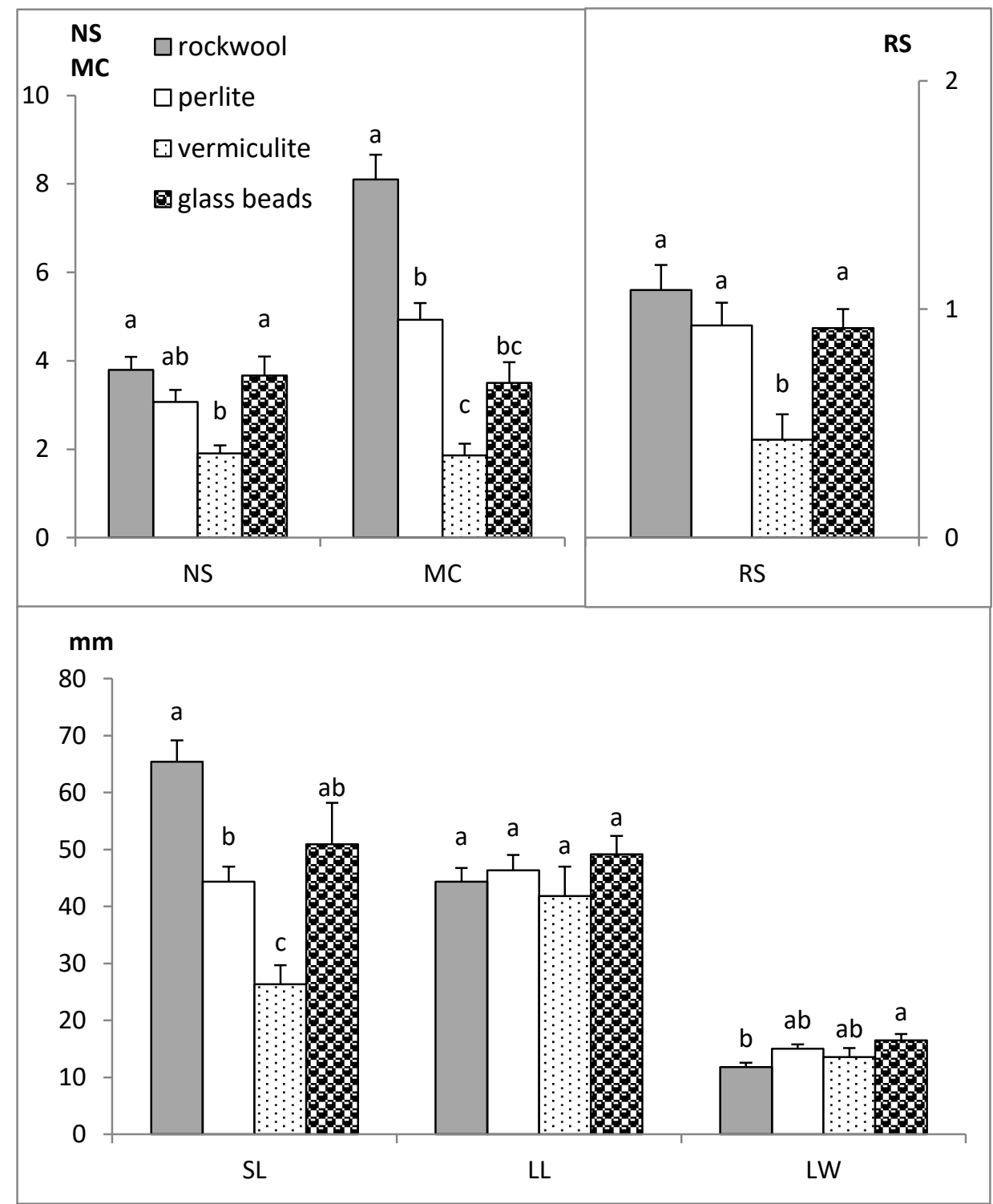

Fig. 3 Effect of the type of support material on proliferation rates and shoot quality of basal explants of clone 90025 cultured in $\mathrm{C} 10$ bioreactors for 5 weeks with aeration for two minutes 16 times per day. Values represent the mean \pm standard error from 2 replicates of 12 shoots each. For each variable, different letters indicate significant differences at $P<0.05$. NS: Number of shoots; MC: Multiplication coefficient; RS: number of rootable shoots per explant; SL: Length of the longest shoot per explant; LL: Length of the largest leaf per explant; LW: Width of the largest leaf per explant. 


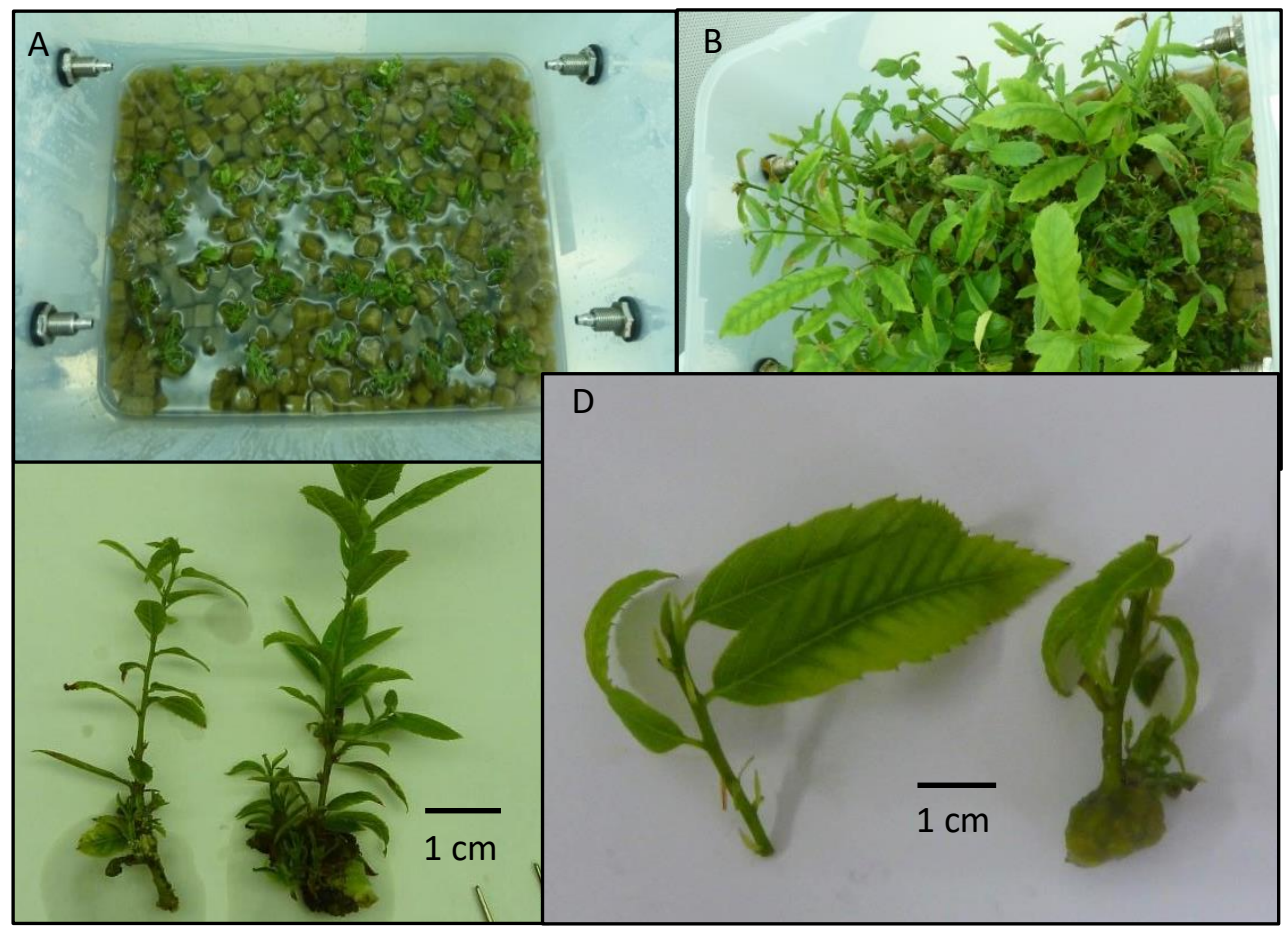

Fig. 4 A-B) Basal explants of clone C063 after being inoculated in (A) a C10 bioreactor and (B) after culture for 5 weeks. (C) Apical (left) and basal (right) explants of clone C053 after culture for 5 weeks in a C10 container. (D) Apical (left) and basal (right) sections of $3 \mathrm{~cm}$ with 3-4 expanded leaves. 


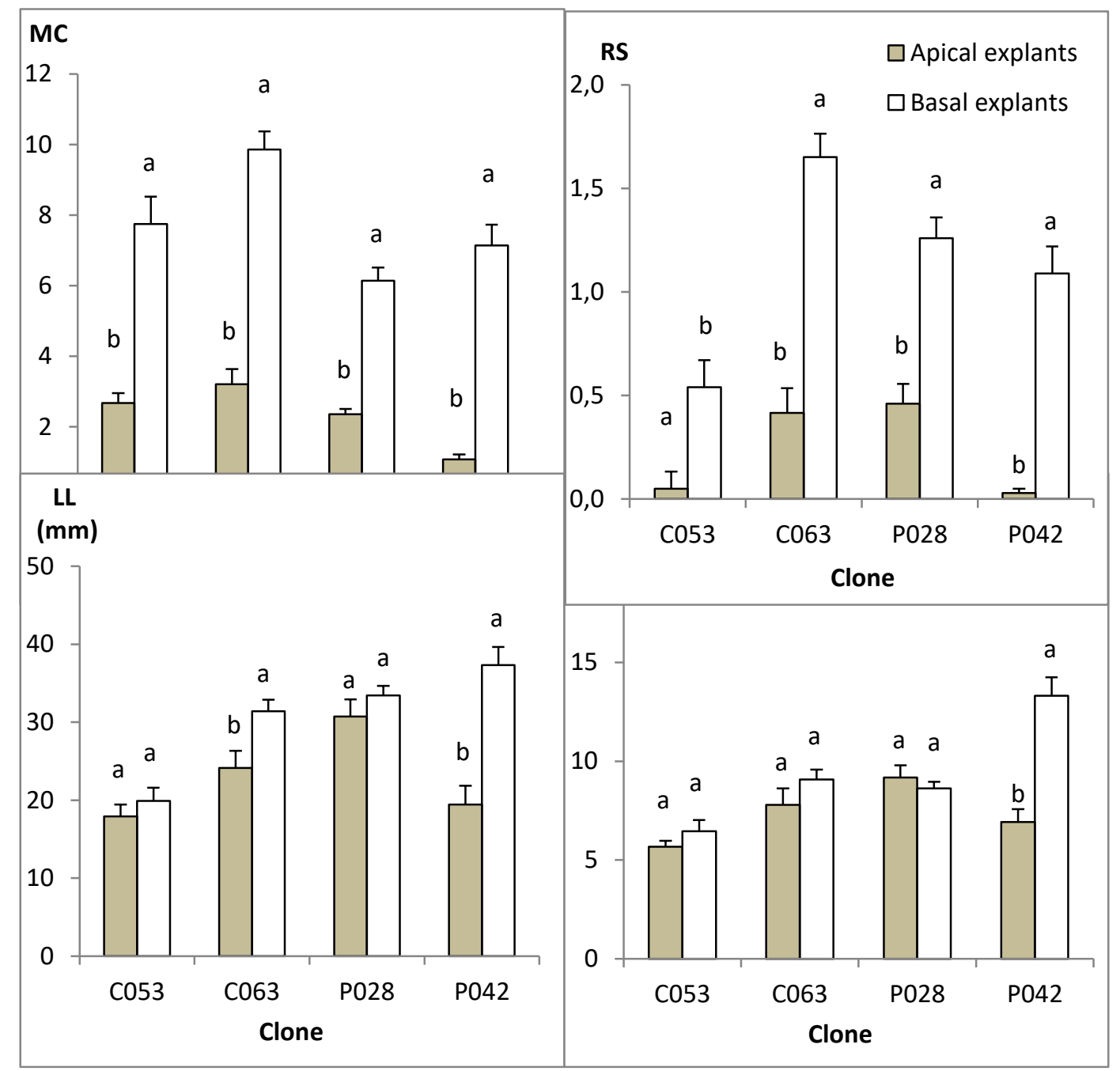

Fig. 5 Effect of the type of explant on the multiplication coefficient (MC), number of rootable shoots (RS), and length (LL) and width (LW) of the largest leaf of basal and apical explants of clones C053, C063, P028 and P042, cultured in $\mathrm{C} 10$ bioreactors with rockwool cubes for 5 weeks with aeration for two minutes 16 times per day. Values represent the mean \pm standard error from 3 replicates of 12 shoots each. For each genotype, different letters indicate significant differences at $P<0.05$ 


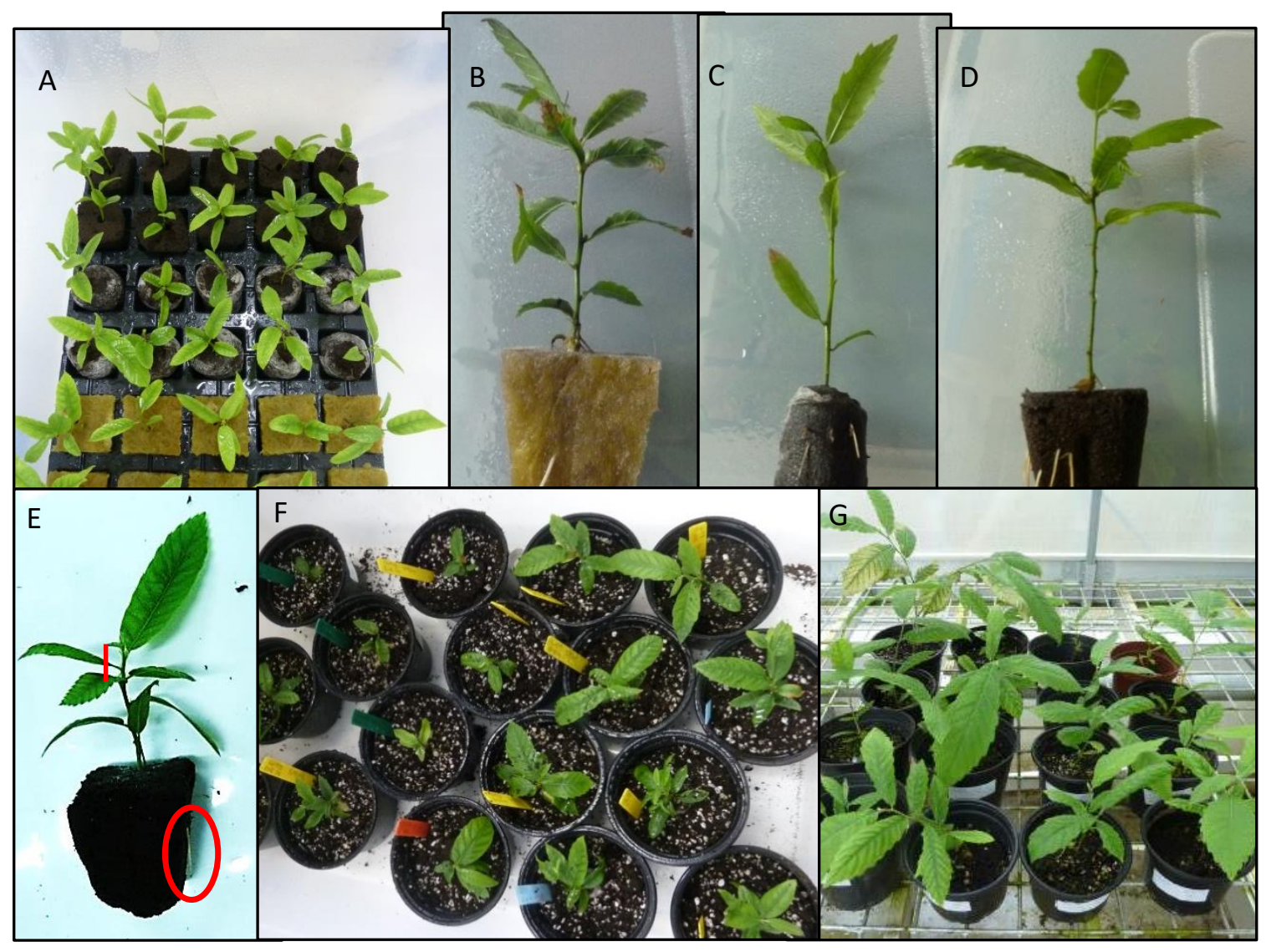

Fig. 6 Ex vitro rooting of shoots cultured in CIS. A) Shoots of clone C063 treated with IBA and inoculated in rockwool cubes, Jiffy ${ }^{\circledR}$ pots and Root! $t^{\circledR}$ sponges. B-D) Rooted shoots of clone C063 in rockwool cubes (B), Jiffy ${ }^{\circledR}$ pots (C) and Root! ${ }^{\circledR}$ sponges (D) four weeks after induction. E) Shoot of clone C053 with an emerging root (red circle) and apical regrowth (red line) three weeks after rooting induction. F) Rooted shoots of clone C053 transferred to pots four weeks after rooting induction. G) Acclimatized shoots of clone $\mathrm{C} 042$ after four weeks in the phytotron and 8 weeks in the greenhouse. 


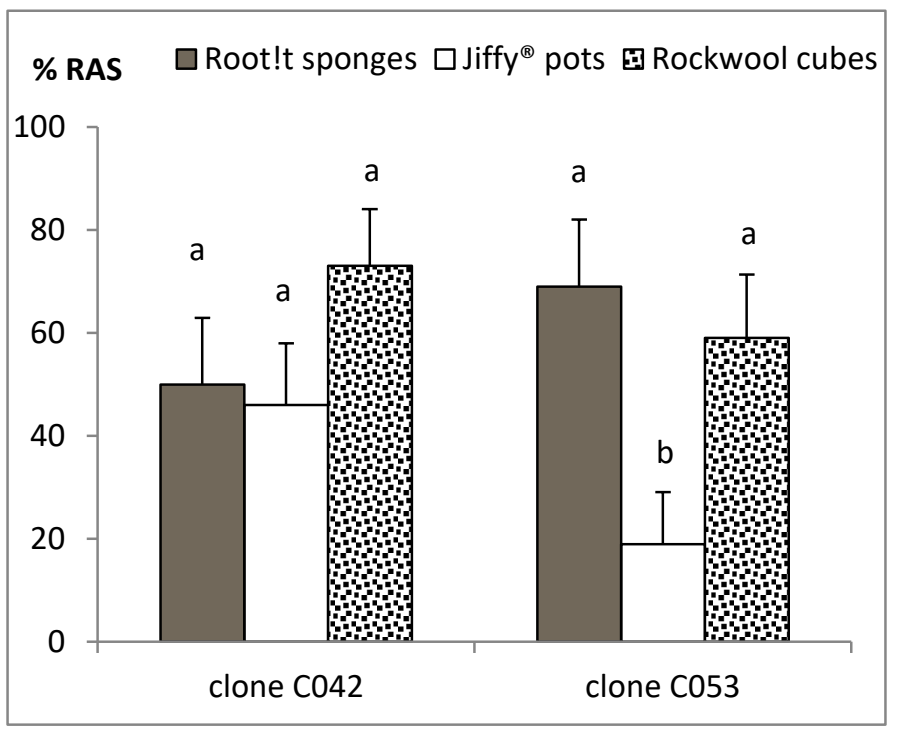

Fig. 7 Rooting and acclimatization capacity of chestnut shoots derived from basal explants cultured in liquid medium and rooted in different substrates. Shoots of clones C042 and C053 were dipped for $1 \mathrm{~min}$ in $1 \mathrm{~g} / \mathrm{I} \mathrm{IBA}(4.9 \mathrm{mM})$ and transferred to Root!t ${ }^{\circledR}$ sponges, Jiffy ${ }^{\circledR}$ pots or rockwool cubes. Plantlets were acclimatized for four weeks in a phytotron before being transferred to the greenhouse for another four weeks, and the percentage of rooted and acclimated shoots was calculated. Values represent the mean from two replicate trials, each with 8-10 shoots per treatment. For each genotype, different letters indicate significant differences at $\mathrm{P}<0.05$ (Kruskal-Wallis test) 